\title{
THE MINERALOGY, PETROLOGY AND GEOCHEMISTR.Y OF ULTRAMAFIC LAMPROPHYRES OF THE YILGARN CRATON, WESTERN AUSTRALIA
}

$$
\text { Foster, }{ }^{(1)} \text { J.G.; Hamilton, }{ }^{(1)} \text { R. and Rock, }{ }^{(2)} \text { N.M.S. }
$$

(1)Western Mining Corporation, 55 MacDonald St, Kalgoorlie, WA, 6430, Australia; (2)Key Centre for Strategic Mineral Deposits, Department of Geology, University of Western Australia, WA, 6009. Australia

Four fields of ultramafic lamprophyres (UML) have so far been discovered in the Eastern Goldfields province of the Archæan $(4.2-2.7 \mathrm{Ga})$ Yilgarn Craton (Figure 1). Bulljah, Lara, Melrose and Norseman. Melrose and Lara have not previously been reported whilst two hitherto unrecorded bodies are here reported from Norseman. The isotopic ages of the intrusives vary from $849 \pm 9 \mathrm{Ma}(\mathrm{Rb}-\mathrm{Sr}$ ) at Norseman (Robey et al., 1986) to $305 \pm 7 \mathrm{Ma}$ at Bulljah (Hamilton and Rock, 1990). No isotopic ages are available for the bodies at Melrose or Lara. The UML at Melrose intrude Archæan granites and geological relationships indicate a pre-Permian post-Archæan age for Lara. These intrusives are significantly younger than the $2.1 \mathrm{Ga}$ Mt Weld carbonatite and the $2.7 \mathrm{Ga}$ Yilgarn calcalkaline lamprophyre dyke swarms (Rock, 1990) which are also located in the Eastern Goldfields province. Peak metamorphism reflecting the last Archæan tectono-thermal event occurred at $2.7 \mathrm{Ga}$, therefore the UML represent the youngest postcratonisation magmatic events so far recorded on the Yilgarn craton.

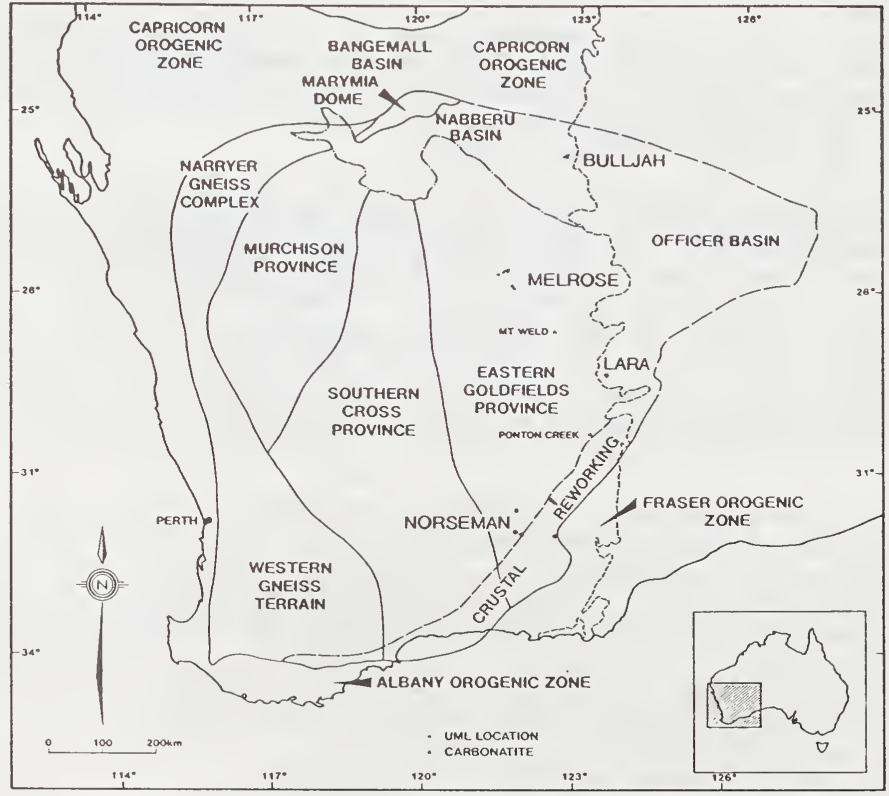

Fig. 1 Location of Yilgarn UML

The bodies typically form dykes which may be discontinuous over several kilometres. The Melrose dykes have widths up to $80 \mathrm{~cm}$ and commonly exhibit flow differentiation on a centimetre scale. This feature has been reported from aillikites in Labrador (Malpas et al., 1986). Four pipe like bodies are also reported, two from Bulljah, one from Melrose 
and one from Lara. The country rock of one Bulljah pipe has been metasomatised and magnetite alteration has occurred over a width of several metres.

The cognate mineralogy of the Yilgarn UML's comprise phenocryst phases of phlogopite and subhedral to euhedral olivines set in a matrix of varying abundances of phlogopite, cpx; calcite, spinel series, apatite, Mg-Mn ilmenite, serpentine, perovskite and Ti-bearing andradite schorlomite garnet; melilite and nepheline are absent. Late stage carbonate veining and segregation features are apparent. Irregular segregation structures often contain chlorite, pyrite and pyrrhotite inclusions (Archer, 1986).

Phlogopites evolve towards tetraferriphlogopite as a result of the replacement of $\mathrm{Al}^{3+}$ by $\mathrm{Fe}^{3+}$ in the tetrahedral site. Rare Ba-bearing phlogopites and feldspars are recorded at Bulljah, olivines are commonly serpentinised, the few fresh grains analysed carry up to 44 wt: MgO. Diopsides range from low AlTi diopside through to titaniferous salite. The presence of both high $\mathrm{TiO}_{2}$ and $\mathrm{Al}_{2} \mathrm{O}_{3}$ in $\mathrm{cpx}$ is particularly diagnostic of ultramafic lamprophyres world-wide (Rock, 1987). The spinels describe a wide continuum from low $\mathrm{Cr}_{2} \mathrm{O}_{3}$ aluminous magnesian chromite (AMC) to high $\mathrm{Cr}_{2} \mathrm{O}_{3}$ titanian magnesian aluminous chromite (TMAC) to low $\mathrm{Al}_{2} \mathrm{O}_{3}$ titanian magnesian chromite (TMC) to high $\mathrm{FeO}_{T}$ titanomagnetite (TM). This trend corresponds to the trend 2 of kimberlite and lamproite spinels (Mitchell, 1986). At both Bulljah and Melrose early grains are often rimmed by later stage more evolved groundmass compositions. We suggest the spinel spectrum represented here is probably magmatic although AMC spinels overlap xenocrysts from garnet and spinel lherzolite. It is envisaged that the AMC trend results from the early co-crystallisation with phlogopite which effectively reduces the amount of $\mathrm{Al}^{3+}$ for $\mathrm{AMC}$ spinel growth.

Xenocryst and macrocryst phases are common. Macrocrystal olivine is ubiquitous at Norseman, grains tend to be anhedral and contrast sharply with the subhedral to euhedral phenocrysts. Picroilmenite is also ubiquitous with compositions ranging from moderate $\mathrm{MgO}(6-12 \mathrm{wt} \%)$, high $\mathrm{Cr}_{2} \mathrm{O}_{3}$ (0.5-2.5 wt\%), moderate Mno (0.5-1 wt\%) to low Mgo (4 wt \%) low $\mathrm{Cr}_{2} \mathrm{O}_{3}(0.0-0.5 \mathrm{wt} \%)$. All picroilmenites have high $\mathrm{FeO}_{\mathrm{T}}$ possibly reflecting formation under relatively oxidising conditions. Mantle derived xenocrysts occur at Bulljah and Melrose. Bulljah concentrates yielded an array of garnets corresponding to Dawson and Stephens' (1975) G1, G3, G5, G9 and G10 categories plus two species of chrome diopsiaes and red-brown aluminous spinels. The garnets indicate that the UML sampled garnet lherzolite, garnet harzburgite, spinel lherzolite, eclogite and lower crustal material on its ascent. Ultramafic nodules are not apparent in surface exposures, but five well rounded spinel lherzolite nodules recovered from diamond drill core represent the only intact mantle sample recovered from beneath the Yilgarn craton. The largest nodule $(6 \mathrm{~cm})$ comprises red-brown spinel, cpx, opx, calcite and serpentine and altered olivine. Analyses of $\mathrm{cpx}$ indicate equilibration at less than $1000^{\circ} \mathrm{C}$ (Jaques, 1989). G3, G5, G9 garnets and $\mathrm{Cr}$-diopsides were recovered from Melrose. No ultramafic nodules were discernible at outcrop but abundant rounded crystal xenoliths exhibiting reaction rims were apparent at one locality. $\mathrm{Na}_{2} \mathrm{O}$ levels in $\mathrm{G} 3$ garnets from both Bulljah and Melrose $(<0.02 \mathrm{wt} \%)$, indicate relatively shallow origin. 
Geochemically the Yilgarn UML's are potassic $\left(\mathrm{K}_{2} \mathrm{O} / \mathrm{Na}_{2} \mathrm{O} \geq 1\right)$, ultrabasic undersaturated $\left(\mathrm{SiO}_{2}=37.57 \%\right)$, primitive $(\mathrm{MgO}=$ $16.74 \%)$, titanian $\left(\mathrm{TiO}_{2}=4.25 \%\right)$ and iron rich $\left(\mathrm{FeO}_{\mathrm{T}}=14.2 \%\right)$. They can easily be discriminated from kimberlites on the basis of their $\mathrm{MgO} / \mathrm{CaO}$ and $\mathrm{SiO}_{2} / \mathrm{Al}_{2} \mathrm{O}_{3}$ ratios (Figure 2a). One analysis in the kimberlite field represents an anomalously olivine rich portion of an ultramafic lamprophyre dyke from Melrose. The $\mathrm{FeO}_{\mathrm{T}}$ of the UMLS are very high with respect to kimberlites and reflect high titanomagnetite content. $\mathrm{Ni}$ and $\mathrm{Cr}$ values are moderate, average $492 \mathrm{ppm}$ and $457 \mathrm{ppm}$. Incompatible elements are typically enriched (average Ba $829 \mathrm{ppm}, \mathrm{Rb} 58 \mathrm{ppm}, \mathrm{Sr} 800$ ppm, Nb 123 ppm, Zr 799 ppm, La $104 \mathrm{ppm}$ and Ce $261 \mathrm{ppm})$. The enhanced light rare earth element (LREE) signature is typical for all members of the lamprophyre clan and is attributed to derivation from a partial melt of metasomatised mantle.

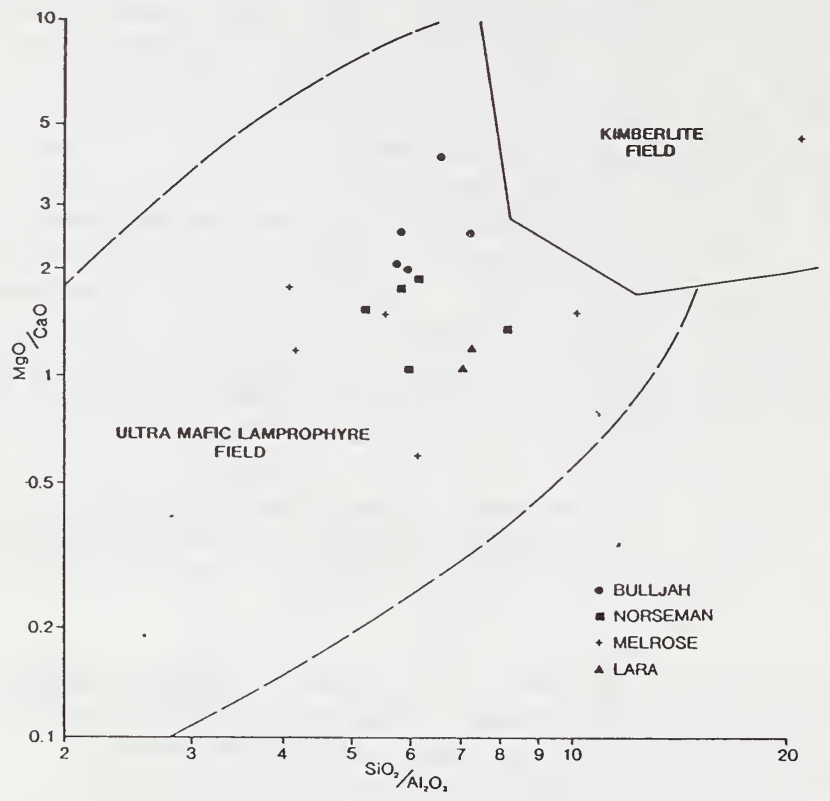

Fig. 2 Discrimination Diagram Based on Whole Rock Geochemistry

We conclude that the UMLs are the youngest member of the following spectrum of mantle-derived magmatic rocks within the Yilgarn craton. Komatiite $(2.8 \mathrm{Ga}) \rightarrow$ basalt $(2.7 \mathrm{Ga}) \rightarrow$ calc alkaline lamprophyre $(2.7-2.6 \mathrm{Ga}) \rightarrow$ peralkaline granitoid $(2.6 \mathrm{Ga}) \rightarrow$ dolerite $(2.5-2.2 \mathrm{Ga}) \rightarrow$ carbonatite $(2.1 \mathrm{Ga}) \rightarrow \mathrm{UML}$ $(0.8,0.3 \mathrm{Ga})$. We suggest that widespread UML magmatism (coupled with the absence of true kimberlites) is the hallmark of intracratonic provinces with an early history of massive komatiite basalt extraction and subsequent tectonic stability. Cratonic provinces with a similar history of development such as the Superior Province may have few or no true kimberlites and low diamond potential.

Archer, N.R. (1986) : Ultramafic lamprophyres of the Yilgarn craton, Western Australia. MSc Thesis, Leicester University, England.

Dawson, J.B. and Stephens, W.F. (1975) : Statistical analysis of garnets from kimberlites and associated xenolith. J. Geol, $83: 589-607$. 
Hamilton, R. and Rock, N.M.S. (1990) : Geochemistry, mineralogy and petrology of a new find of ultramafic lamprophyres from Bulljah Pool, Nabberu Basin, Yilgarn craton, Western Australia. Lithos, 24, 275-290.

Jaques, A.L. (1989) : Report on peridotite xenoliths from Bulljah Pool ultramafic lamprophyres. BMR Canberra, ACT.

Mitchell, R.H. (1986) : Kimberlites: Mineralogy, Geochemistry and Petrology. Plenum, New York, 442p.

Malpas, J., Foley, S.F. and King, A.F. (1986) : Alkaline mafic and ultramafic lamprophyres from the Aillik Bay area, Labrador. Canadian Journal of Earth Sciences, 23, 1902-1917.

Robey, J.V.A., Bristow, J.W., Marx, M.R., Joyce, J., Danchin, R.V. and Arnott, F. (1986) : Alkaline ultrabasic dikes near Norseman, Western Australia in J. Ross, Ed., Kimberlites and Related Rocks Volume 1, p382-391. Blackwell Scientific Australia.

Rock, N.M.S. (1991) : Lamprophyres: Blackie, Glasgow, 285p. 